\title{
Verification of a Combined Sewer Model for Urban Drain Improvement
}

\author{
Hala Baroudi, Walter Alix and Philip Sanzica
}

Model verification for a large combined sewer system can be expensive and timeconsuming. Frequently, a governmental entity cannot afford to expand their flow meter network throughout an entire sewer system to obtain sufficient data for model verification. In an attempt to limit the costs related to the verification process, other avenues using available data were explored, while still maintaining a high level of reliability.

The objective of this chapter is to document two techniques used to verify a large combined sewer system modeled in Oakland County, Michigan. Initially, an area representing approximately $10 \%$ of the district modeled was verified with flow metering data. Secondly, to avoid the cost of installing additional meters in large diameter sewers, the overall model was verified by comparing modeled hydraulic grade lines with reported basement flooding elevations and measured high water marks.

\subsection{Historical Background}

The Twelve Towns Drainage District is a combined sewer system designed to serve a drainage area of approximately 24,500 acres $(10,000 \mathrm{ha})$. The District is located in Southern Oakland County (see Figure 14.1), just north of Detroit, Michigan.

Baroudi, H., W. Alix and P. Sanzica. 1999. "Verification of a Combined Sewer Model for Urban Drain Improvement." Journal of Water Management Modeling R204-14. doi: 10.14796/JWMM.R204-14.

(C) CHI 1999 www.chijournal.org ISSN: 2292-6062 (Formerly in New Applications in Modeling Urban Water Systems. ISBN: 0-9697422-9-0) 


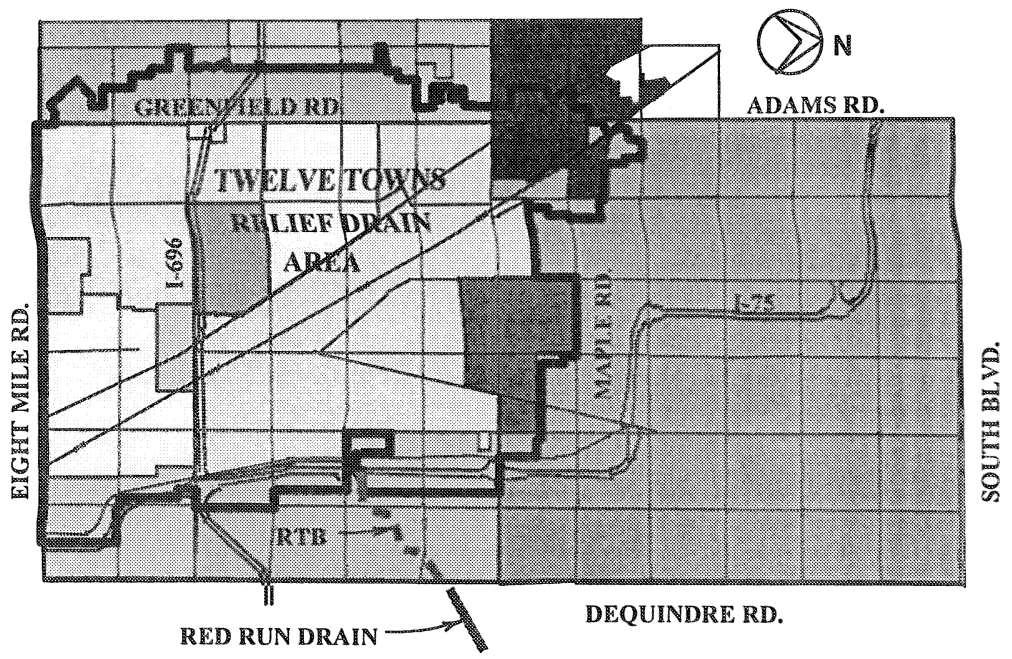

Figure 14.1 Twelve Towns Relief Drain-location map.

The communities served by this combined sewer system developed from the late 1920s and continued through the early 1970s. The land use is primarily medium to high-density, single-family residential with commercial and light industrial areas. The District is considered to be fully developed.

The sewer service was typical for that time period, with one combined sewer to transport both the storm and sanitary needs of the growing metropolitan area. A wastewater treatment plant was replaced in the 1940 s with a connection to the expanding service network of the Detroit Water and Sewage Department. Until 1965 , combined sewage continued to overflow unabated during rain events to the Red Run Drain, a tributary of the Clinton River in the Lake St. Clair Watershed. A weir structure was constructed at that time to take advantage of in-system storage. A 62 million gallon (234 million liter) retention treatment facility (RTF) was constructed in 1972 to further control combined sewer overflows.

The original combined sewers were deemed inadequate and were relieved by a major improvements project in the late $1950 \mathrm{~s}$, and early 1960 s. This project was called the Twelve Towns Relief Drain.

The Twelve Towns Relief Drain is divided into three main branches: North, Middle and South. They have a combined total capacity of approximately 210 cubic meters per second (7,500 cfs) and overflow into a 235,000 cubic meters (62 million gallons) retention treatment basin.

The area served by the North Arm Branch of the Twelve Towns Drain continued to experience basement flooding during intense rain storm events. There are eight communities that have areas tributary to the North Arm Branch. These communities have varying degrees of basement flooding within their tributary areas. 


\subsection{Study Approach}

Currently, the North Arm Branch of the Twelve Towns Drain continues to experience basement flooding. This Branch accounts for approximately 8,000 acres (3253 ha) of the entire Twelve Towns District. The City of Royal Oak is the largest community in the North Arm Branch and experienced the worst basement flooding. Royal Oak petitioned the Oakland County Drain Commissioner to construct additional County sewers to mitigate the flooding situation.

In order to evaluate alternatives for improvements, XP-SWMM was employed to simulate hydrologic and hydraulic conditions of the combined sewer network. The state regulatory agency, the Michigan Department of Environmental Quality (MDEQ), was also interested in the impact of the improvements on the performance of the RTF.

Using XP-SWMM, a model was developed for the existing and future conditions as an aid in designing additional relief sewers. Verifying that the model accurately represented the combined sewer network was an important but difficult task. The outlets from the North Arm Branch are a 14.25-foot by 14-foot $(4.34 \mathrm{~m}$ by $3.27 \mathrm{~m})$ box and 15 -foot $(4.6 \mathrm{~m})$ horseshoe. The participants of this project recognized that it would be cost-prohibitive to install even a temporary flow meter. It was decided to adopt a two-step approach to model verification: partial flow metering; and correlating the hydraulic grade line of the model with reported high water marks and basement flooding elevations.

\subsection{Model Calibration using Meter Data}

Flow monitoring was conducted in a junction chamber at Nakota Road and Olivia Avenue within the City of Royal Oak (see Figure 14.2 for location). The service area upstream of the junction chamber was approximately 800 acres, or $10 \%$ of the North Arm Branch. In an attempt to verify flow splits at the junction chambers and flows computed by the model, data was collected from the meters for the period between April 10 and June 25, 1996.

The flow meter data indicated that all of the dry weather flow and the low intensity storm flows were contained in the 6.0 -foot $(1.8 \mathrm{~m})$ Nakota Road sewer. No runoff was observed in the 5.5 -foot $(1.7 \mathrm{~m})$ Twelve Towns Relief Sewer in Olivia Avenue under these conditions. This is not consistent with the configuration of the junction chamber shown on the as-built drawings (see Figure 14.3). The drawings implied that most of the flow should have been directed to the Olivia Avenue sewer. This significantly affected the model results and cast doubt on the model accuracy. 


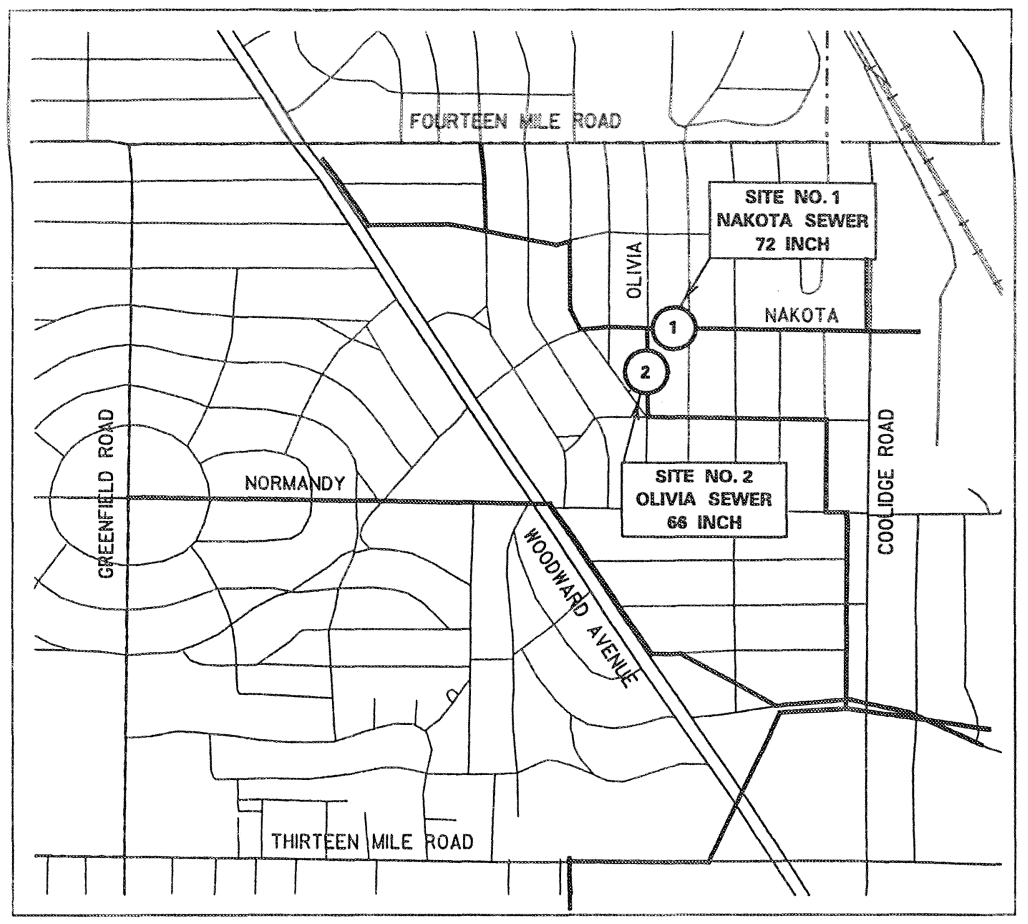

Figure 14.2 Meter site map.

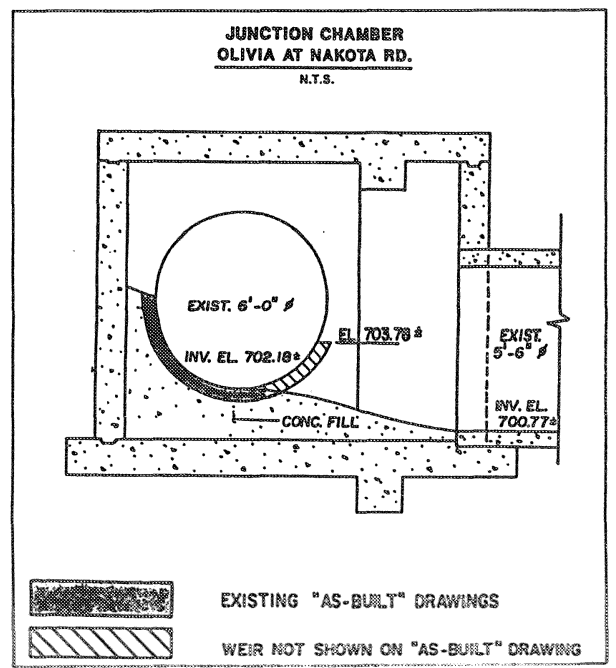

Figure 14.3 Junction Chamber Olivia at Nakota Rd. 
The Oakland County Drain Commissioner's Office inspected the junction chamber at Nakota/Olivia Avenue to confirm the flow meters records. The inspection revealed a twelve-foot $(3.6 \mathrm{~m})$ long, 1.6-foot $(0.5 \mathrm{~m})$ high weir constructed along the Nakota Road sewer preventing low flows from being diverted to the Olivia relief sewer. The inclusion of this weir enables the model to accurately replicate observed flows.

Flow data for Olivia and Nakota sewer were input into the model to calibrate the weir. The weir was best represented in the model by using an equivalent pipe with a bottom invert of $703.8 \mathrm{ft} .(214.6 \mathrm{~m})$ (see Roesner, 1989). The results of the calibration for the June 12, 1996 event are shown in Figures 14.4 and 14.5.

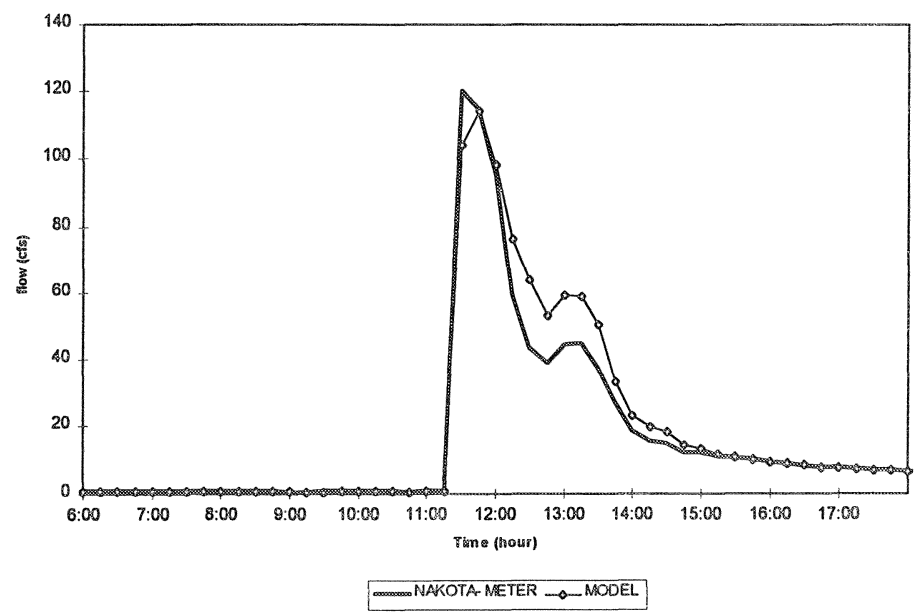

Figure 14.4 Flow split calibration, June 12-Olivia Sewer.

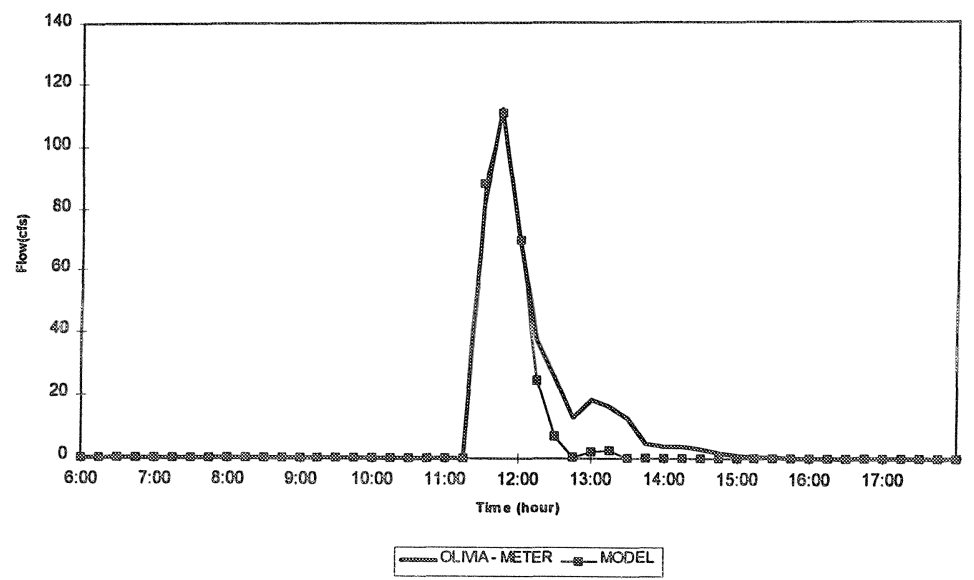

Figure 15.5 Flow split calibration, June 12-Nakota Sewer. 
Once the flow split at the junction chamber was calibrated, rainfall data for the wet weather events during the flow monitoring period were entered into the model.

Calibration results for June 12, 1996 and June 17-18, 1996 events are shown in Figures 14.6 to 14.9. These figures compare observed and computed flows Rain data in 15-minutes increment is plotted on the same figures.

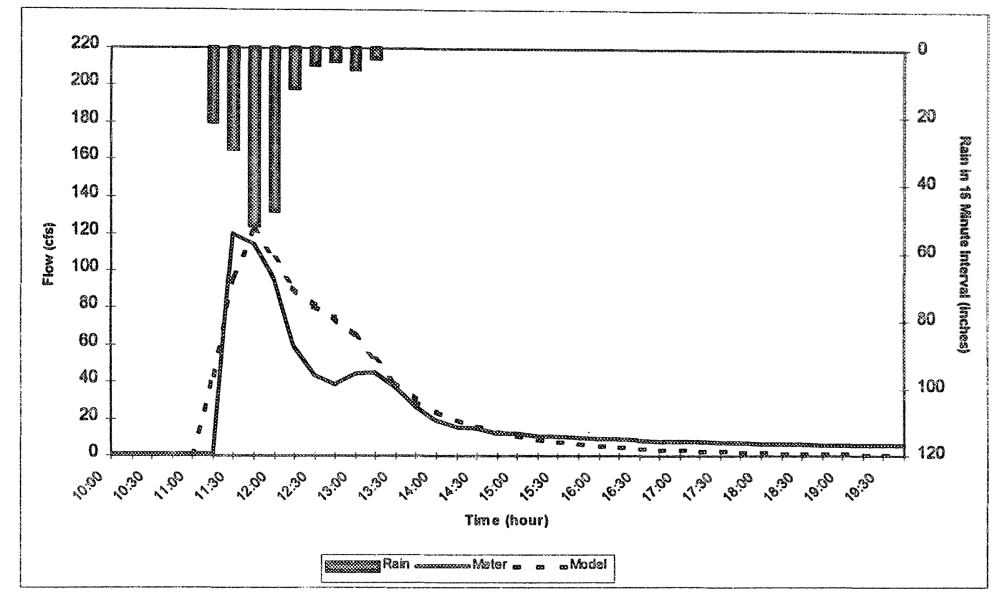

Figure 14.6 Model calibration using raingage 833, Nakota Sewer, June 12, 1996

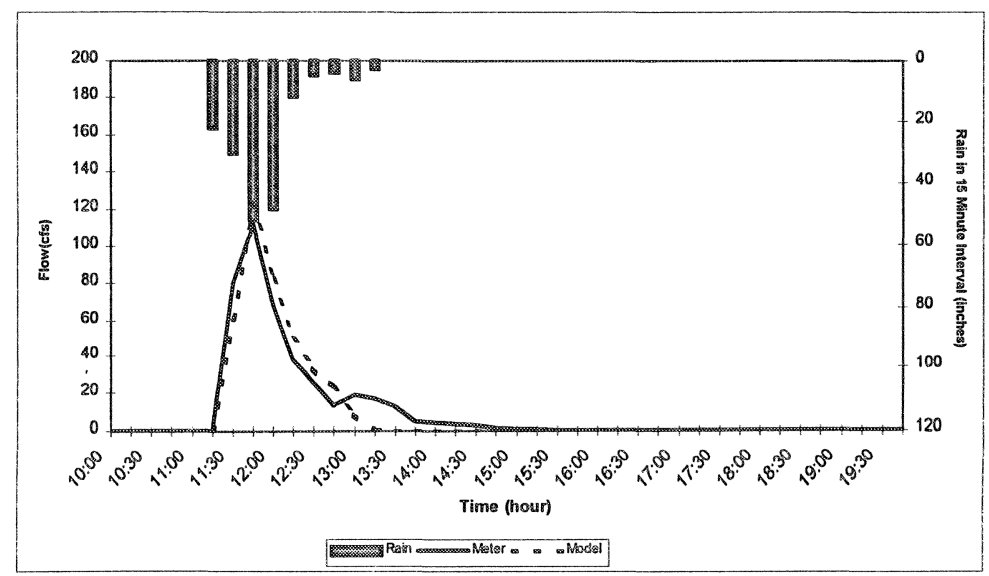

Figure 14.7 Model calibration using raingage 833, Olivia Sewer, June 12, 1996

The model parameters used for the calibration process included:

- depression storage for impervious and pervious areas;

- maximum and minimum infiltration rate; 


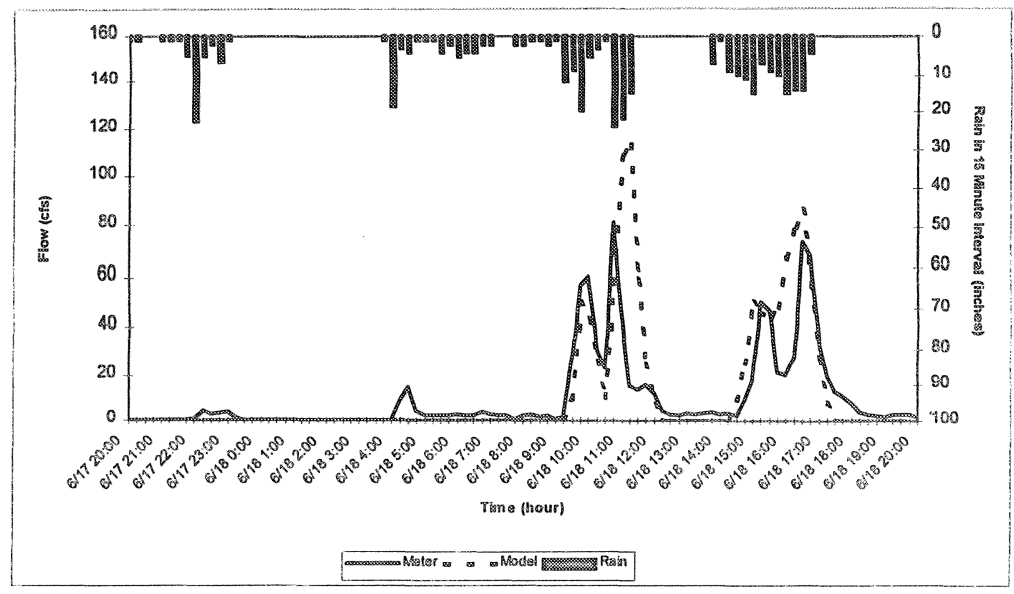

Figure 14.8 Model calibration using raingage 833, Nakota Sewer, June 17-18, 1996

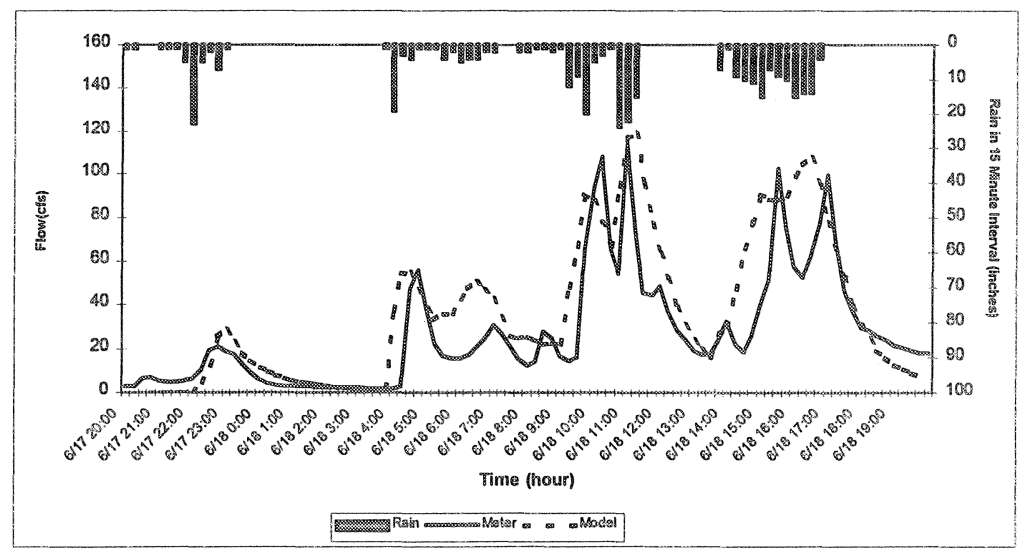

Figure 14.9 Model calibration using raingage 833, Olivia Sewer, June 17-18, 1996

- decay rate of infiltration;

- overland Manning's " $n$ " value;

- overland slope;

- subcatchment width;

- subcatchment impervious area; and

- runoff module transportation conduit length.

Figures $14.5,14.6,14.7$ and 14.8 indicate that the computed flows are sufficiently accurate to warrant acceptance of the model. 


\subsection{Model Verification using known Water Elevations}

The second phase of the model verification involves correlating the hydraulic grade (HG) line projected by the model with estimated basement flooding elevations. In addition, the City of Royal Oak collected water surface elevations at critical manholes in the sewer system which were also compared to the computed HGs. The latter measurements are referred to hereafter as high water marks.

The basement flooding elevations and high water marks proved to be an invaluable resource in verifying the model. Although the basement flooding reports were subject to a certain degree of interpretation in establishing their exact elevations, the information nevertheless was determined to be reliable. In addition, these elevations are a direct measurement of the hydraulic conditions of the system and are not dependent on velocity readings by a flow meter which may be difficult to verify. Oftentimes, a community will collect this type of data during a major event and it may be the only means for assessing the severity of the storm and the performance of the system.

Figure 14.10 represents locations of flooded basement within the city of Royal Oak during the August 18-19, 1990 storm event. Locations of high water marks measured by the city are also shown on Figure 14.10.

Shown on Figure 14.11 are the 60-minute rainfall intensities that were estimated to occur during the event. The peak one-hour rainfall intensity averaged 2.3 inches $(58 \mathrm{~mm})$ over the Royal Oak area and 2.0 inches $(51 \mathrm{~mm})$ over the neighboring areas of Berkeley, Beverly Hills, Birmingham and Troy.

The interceptor reaches considered in this analysis are shown on Figure 14.10. The following is a brief description of each interceptor location:

- Interceptor 1 runs along Twelve Mile Road and Woodland between the Retention Treatment Facility (RTF) and Mandalay Road.

- Interceptor 2 runs along Campbell Road between Twelve Mile Road and Whitcomb.

- Interceptor 3 runs along Windemere, Woodlawn and Washington.

- Interceptor 4 runs along Alexander from Twelve Mile Road, crossing Thirteen Mile Road up to Nakota.

- Interceptor 5 is the profile along Nakota between Crooks and Olivia.

- Interceptor 6 is the Twelve Town Drain from the RTF along Stephenson Hwy., Thirteen Mile Road, Coolidge Hwy. and up to Olivia.

- Interceptor 7 is along the Baldwin Drain.

Rain data for the August 18-19, 1990 storm events were entered into the model and the results are illustrated on Figures 14.12 through 14.17. 


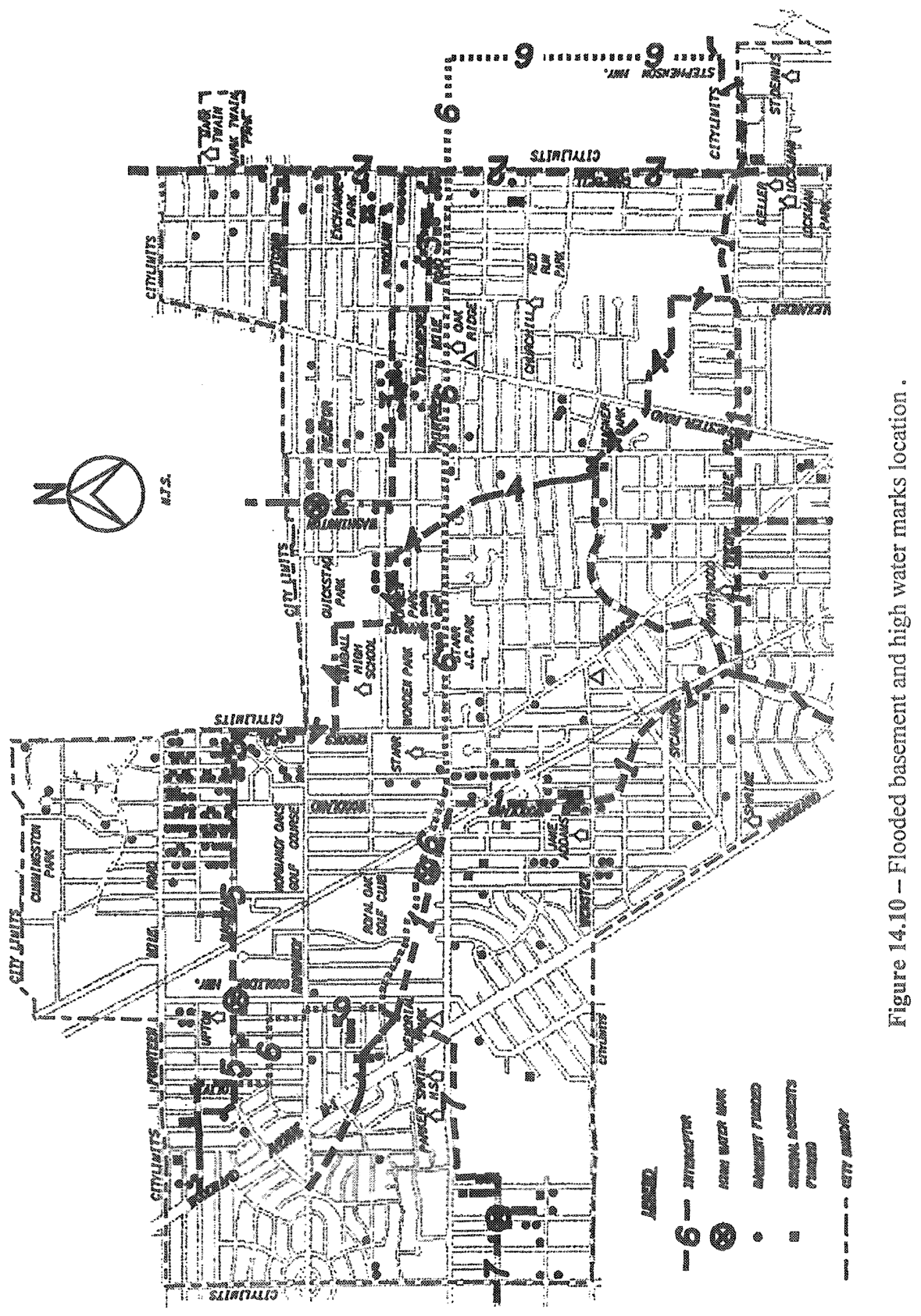




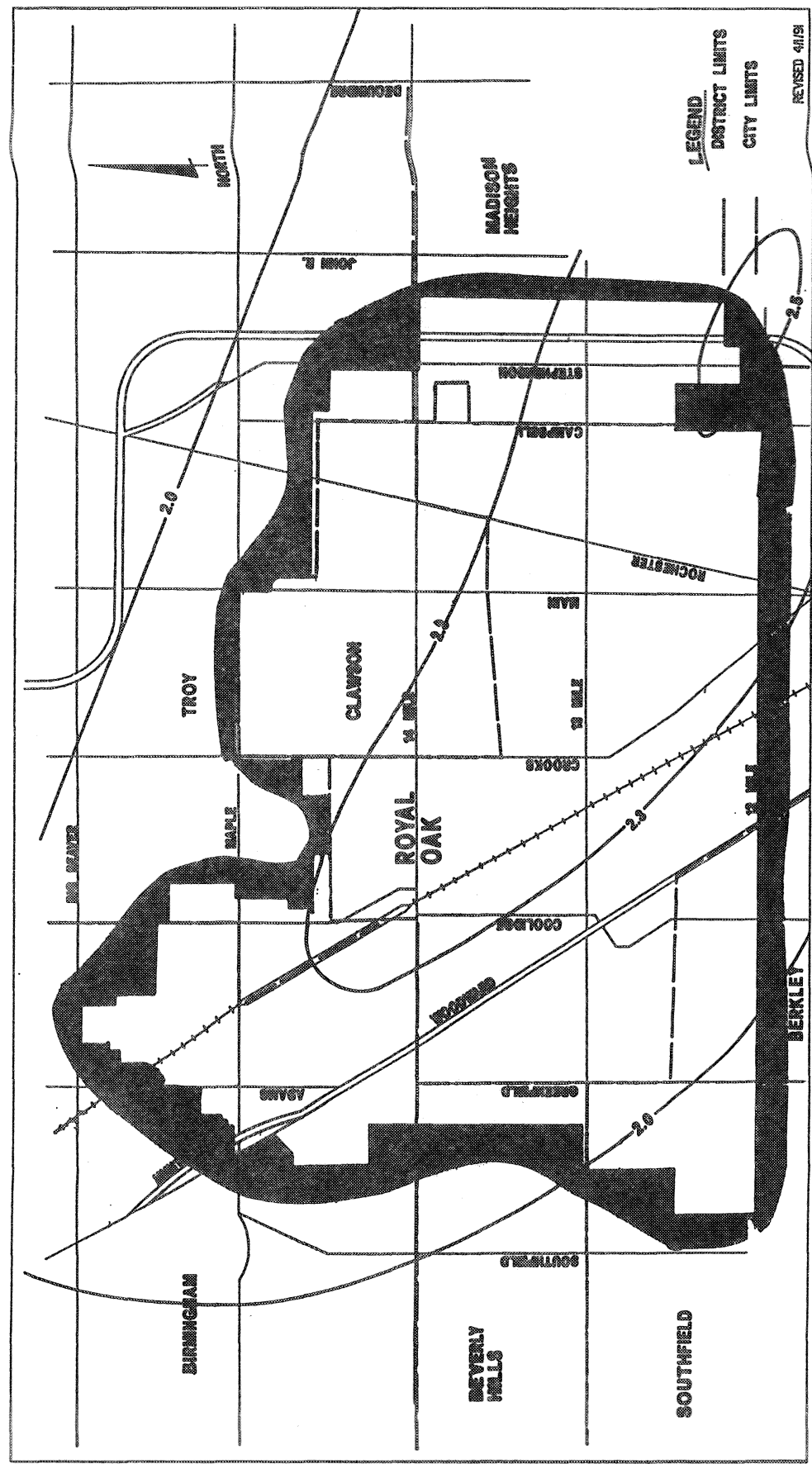

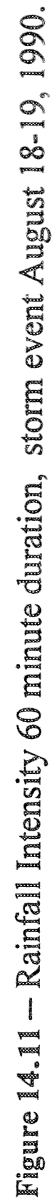


From Figure 14.10, the locations of the flooded basements are as follows:

- South of Thirteen Mile Road near the County interceptor in Woodland. The model results agree with the existing condition as illustrated in Figure 14.12. A high water mark was measured in the 78-inch $(1981 \mathrm{~mm})$ pipe at an elevation 16.7 feet $(5.1 \mathrm{~m})$ above the pipe invert. The computed water depth was approximately 17.8 feet (5.4 m).

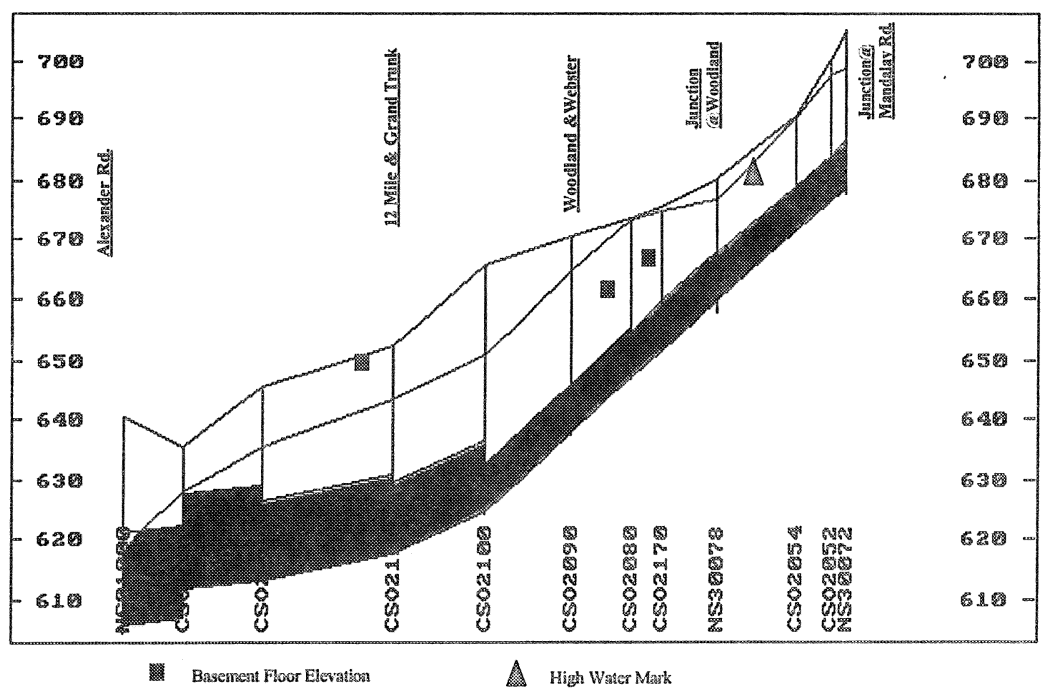

Figure 14.12 Profile along county drain from PCF to Mandalay Rd. Interceptor \# 1, August 18-19, 1990

- West of Campbell Road, between Thirteen and Fourteen Mile Roads, in an area served by the county interceptors in Campbell and Windemere. A high water mark was measured in the 84-inch $(2134 \mathrm{~mm})$ pipe at an elevation 13.85 feet $(4.22 \mathrm{~m})$ above the pipe invert. The resulting hydraulic grade line agreed with the basement flooding locations along Windemere. The computed water depth was approximately 12.0 feet $(3.66 \mathrm{~m})$. The results compare favorably with the existing condition as shown in Figure 14.13 and Figure 14.14 .

- A large concentration of flooded basements are located south of Fourteen Mile Road, from Briarwood east to Crooks (close to the County interceptor in Nakota and Crooks Roads). Similar computed results are in Figure 14.15 and 14.16. A high water mark was measured in the 78 -inch $(1981 \mathrm{~mm})$ pipe at an elevation 12.85 feet $(3.92 \mathrm{~m})$ above the pipe invert. The computed water depth was approximately 15 feet $(4.57 \mathrm{~m})$. 


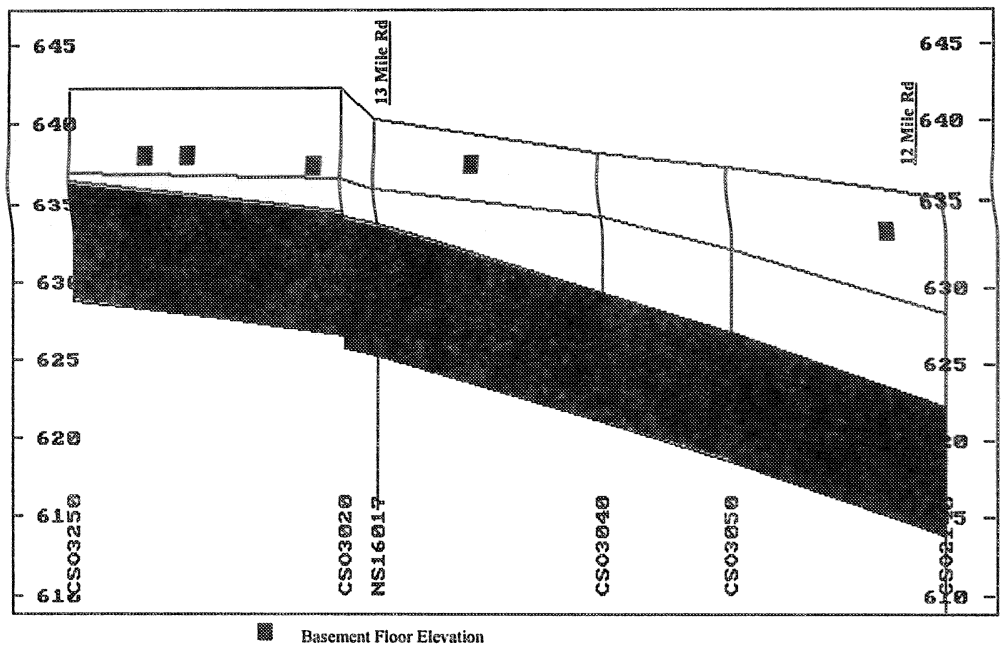

Figure 14.13 Profile along Campbell Rd. Interceptor \# 2, August 18-19, 1990.

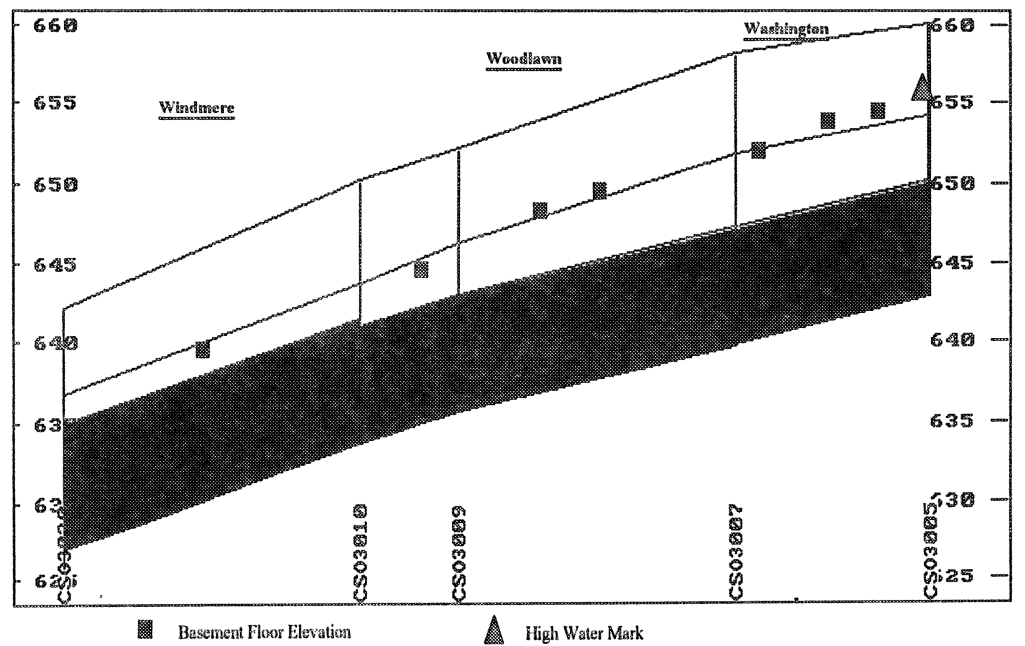

Figure 14.14 Profile along Washington, Woodlawn, and Windemere Interceptor \# 3, August 18-19, 1990.

- Near Judson Avenue, west of Beaumont Hospital, near the Baldwin Branch of the County interceptor system, the model results agree with existing conditions (see Figure 14.17). A high water mark was measured in the 36 -inch $(914 \mathrm{~mm}$ ) pipe at an elevation 12.45 feet $(3.8 \mathrm{~m})$ above the pipe invert. The computed water depth wasapproximately 14 feet $(4.27 \mathrm{~m})$. 


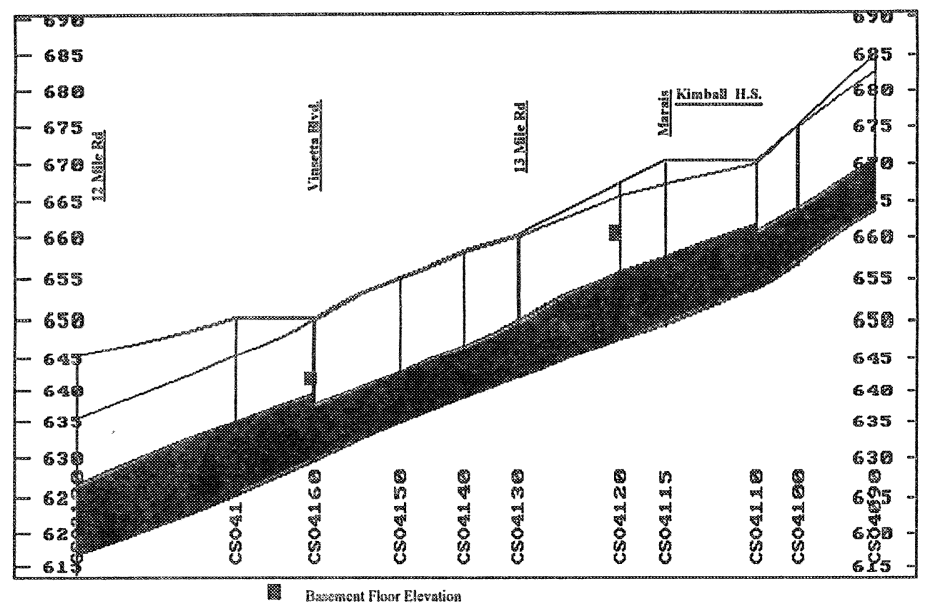

Figure 14.15 Profile along County Drain from Twelve Mile Rd. to Nakota Interceptor \# 4, August 18-19, 1990.

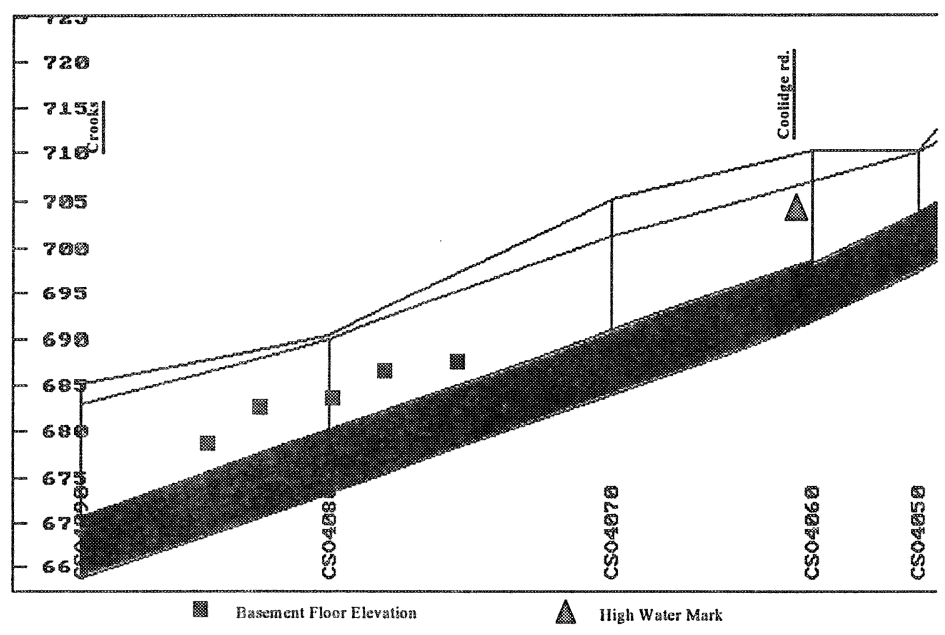

Figure 14.16 Profile along Nakota Interceptor \# 5, August 18-19, 1990

In a similar fashion to the event of August 18-19, 1990, two additional events were evaluated: July 16, 1995 event and July 2, 1997.

During the July 16, 1995 storm event, the peak rainfall intensity averaged 1.74 inches $(4.26 \mathrm{~mm})$. Royal Oak reported 53 basements flooding. Rain data for the July 16,1995 storm event was entered into the model. The results agreed favorably with the observed condition. 


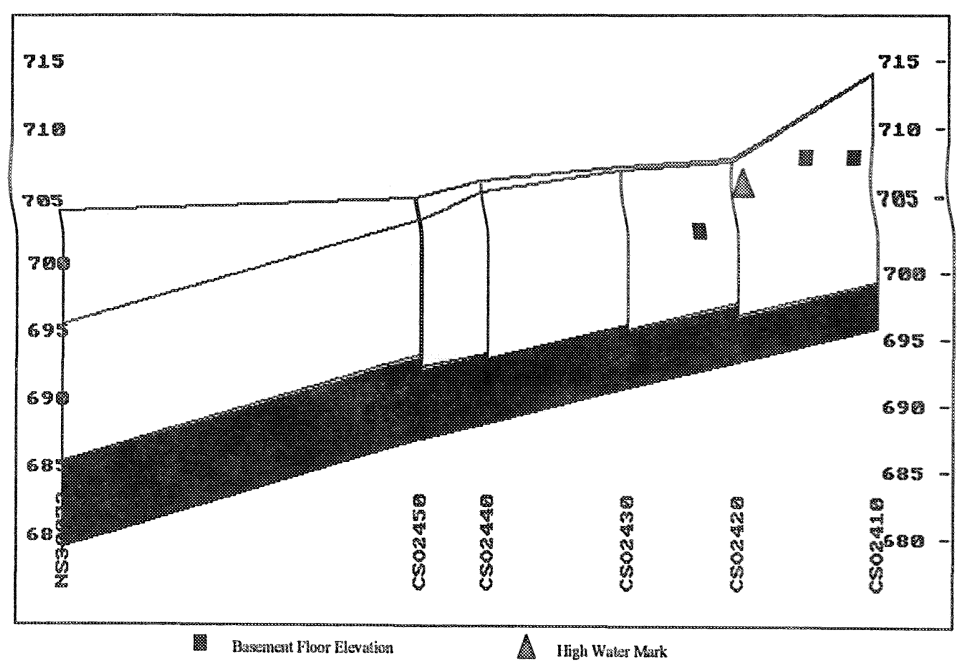

Figure 14.17 Profile along Baldwin Branch Interceptor \# 7, August 18-19, 1990.

During the July 2, 1997 storm event, the peak rainfall intensity averaged 2.25 inches $(57.2 \mathrm{~mm})$ over 75 minutes. Royal Oak reported 137 basements flooded. This event is similar to the first event discussed (August 18-19, 1990). Again, the model agreed with the observed condition.

\subsection{Summary and Conclusion}

This chapter presents a unique case of model verification for a large and complex watershed. The computed hydraulic grade lines for three different storm events agreed favorably with the reported basement flooding locations and elevations. Also, the flows generated by the model are similar to the observed. It was concluded that the model was sufficiently verified to reflect conditions that exist in the North Arm Branch of the Twelve Towns Drain.

The model was used to recommend a cost-effective solution to the basement flooding in the North Arm Branch. In addition, the model demonstrated to the Michigan Department of Environmental Quality staff that the RTF would not be adversely affected by the proposed improvements.

\section{Acknowledgments}

The authors gratefully acknowledge those who supported and guided this work: Keith McCormack at Hubbell, Roth and Clark, Inc; City of Royal Oak; Michigan Department of Environmental Quality. 


\section{Bibliography}

Hubbell, Roth and Clark Inc., 1991, Twelve Towns Drain North Arm Study Phase I, prepared for City of Royal Oaks. April 1991.

Technical Paper No. 40, Rainfall Frequency Atlas of the United States, May 1961.

Hubbell, George E., 1966. Effect of Storage and Skimming on Combined Sewage Overflows, presented at the $39^{\text {th }}$ annual conference of the Water Pollution Control Federation, Kansas City, Mo., September 25-30, 1966.

Biehl, Theodore G. , and M. David Waring, 1972 In-Line Structure Stores and Treats Combined Overflow, ASCE September 1972.

Roesner, Larry A., JohnA. Aldrich and Robert E. Dickinson, 1989. Storm Water Management Model User's Manual Version 4, EXTRAN Addendum. USEPA, Athens, Georgia. February 1989.c200pp.

Sangal, S. and S.R. Bonema. 1993."A Methodology for Calibrating SWMM Models." Journal of Water Management Modeling R176-24. doi: 10.14796/JWMM.R176-24. 
